\title{
Effective Education in a College in Bangladesh: From Managerial to Transformational Leadership
}

\author{
M. Hasan Sarowardy¹, Deb Proshad Halder ${ }^{2}$, Sharon Campbell Phillips ${ }^{3}$ \\ ${ }^{1}$ Department of Political Science, Jashore Government Girls' College, Jashore, Bangladesh \\ ${ }^{2}$ Department of English, Jashore Government Girls' College, Jashore, Bangladesh \\ ${ }^{3}$ Department of Education, University of the People, Pasadena, CA, USA \\ Email: hasan13bcs@gmail.com, debproshadhalder@gmail.com, beautifulblushes@yahoo.com
}

How to cite this paper: Sarowardy, M.H., Halder, D.P. and Phillips, S.C. (2019) Effective Education in a College in Bangladesh: From Managerial to Transformational Leadership. American Journal of Operations Research, 9, 219-234.

https://doi.org/10.4236/ajor.2019.95014

Received: August 1, 2019

Accepted: September 14, 2019

Published: September 17, 2019

Copyright $\odot 2019$ by author(s) and Scientific Research Publishing Inc. This work is licensed under the Creative Commons Attribution International License (CC BY 4.0).

http://creativecommons.org/licenses/by/4.0/

\begin{abstract}
This paper is a study on the compulsion of transformational leadership from the part of the principal of this era when the demography of the students are changing exponentially, when the globe is experiencing massive changes in methods and techniques in educational process but the institutions remain the same as its ethics and operational strategies. The time is eloping when an educational head earns praises due to their prominence and performance in managerial functioning. But this paper tends to focus on several persisting challenges in these educational institutions like huge gap between teacherstudent ratio, students' increasing technological oriented learning, teachers' lack of knowledge of multimedia class operation, girls' little rate of enrolment in higher level of education, early marriage of school going girls and ensuring quality education to girls as per the demand of SDG 4 by 2030. This paper fosters the idea that a transformational head of the institution can be successful in this chase of challenges as he involves everyone to activities in order to reach goal. He works with the other members as a team member and thus a challenge of an institution turns to be liability to all.
\end{abstract}

\section{Keywords}

Effective Education, Manager, Transformer, Leadership, Role of Principal, Bangladesh

\section{Introduction}

The term "Effectiveness" implies several factors to measure the extent of reaching to that predetermined point or close to that indicated point of efficacy. This 
term superimposed preceding the apparently abstract ideation, Education, entails this apparently abstract ideation comprises several measuring standards to denote that the imparted education can be categorized as effective. Ajayi \& Ekundayo [1] has conviction on effectiveness of educational institution for the weighing of educational effectiveness fostering "learning environment, monitoring system of student's progress, school facility and teacher's quality” (p. 33).

The reference [2] reflects on the prearrangement of an institution to what extent the institution labors with the interaction between the teachers and the students as to claim honor of achieving the goals and application of methodologies preordained through the written document, a curriculum (p. 254). It generates the thought that a principal, the administrative as well as academic leader, preserves little scope to formulate, fabricate, modify and impose innovation in the academic fate of that institution that rests on the assumption of managerial performance that the leader is waged to implement as per the requirements imposed through curriculum.

The managerial role has, significantly, been specified through [3] that projects the idea of managerial roles as "the specified set of activities" performed as as per the directives specified to observe the extent of implementation the manager has ensured (p. 42). The vision, mission and curriculum formulation for the educational institutions (specially Government institutions of Elementary, secondary and higher secondary levels of Bangladesh) are set through and implemented through top-down process that negates the revolutionary decision making, that requires to address emerging academically changing trends, from the part of the institutional heads as per the conditioned principality as Prodhan [4] retorts that the educational administration, which tends to decide the way of institutional management both in administrative as well as academic level, retains centralization creating rigidity and having no guideline to take immediate actions for the peripheral institutions regarding emerging issues and challenges as the central authority formulates policies with the justified records of some parishioner schools and colleges (p. 21).

This paper tends to delve how to ensure effective education that implies sustainability and the creation of the learners such a way to raise the capability of combatting the global challenges and justify the effectiveness and time befitting demand 1) whether managerial leadership lags behind with the efficiency measurement for the dynamism of educational challenges, 2) whether transformational leadership necessitates its urgency to be operational in the perspective of Bangladesh in order to achieve sustainability, capability, and prominence of an educational supremacy for the core beneficiaries, "the learners of the globally digital citizenship" [5] (para. 13).

\section{Literature Review}

Lara [6], the senior Editor, of The Economist Intelligent Unit has prescribed several key factors aiming at issues and challenges of $21^{\text {st }}$ century effective education as 1) students allowing to achieve soft skills alongside foundational lite- 
racy, 2) teachers enabling to use a range of strategies to deliver effectively, 3) technology supported teaching strategy and 4) the autonomy of teacher; are the corner stones to ensure the necessary conditions for the globally accredited education, and the distinctive factors as challenges are reflected like 1) resource constraints and 2) the deciding pace of innovation. The greatest role players for ensuring effective education is the teachers according to the preceding reference who must ensure the students to learn what they require (soft skills) and the teachers need to be equipped with the new methods, techniques and tools to disseminate the knowledge. But autonomy of the teachers must be grunted, firstly, as the study conducted by Lara [6] denotes an institution well equipped and praiseworthy furnished scores less than an institution allowing much autonomy to the teachers (para. 7). Again, the idea of autonomy procreates the idea of leadership embedded in the educational institutions as innovation may require immediate solution to imply and the head of that institution decides on the action without prior consent of the centralized administration.

Leadership, here, correlates with the autonomy, specially the presence of autonomy, as the researchers Daun \& Mundy [7] designates the pressure of globalization requires the enhancement of human capital and the principal of an institution adds value to this idea by ensuring the required achievements of the students all through the assessments [8] (p. 1). The reference [9] has recommended the autonomy of the principals as their collaborative research work validates the idea with greater significance that giving school leaders greater autonomy implies the opportunity for the institutional leader, the principal, to manage resources, personnel, and instructional programs which ultimately results in the improvements of student outcomes.

However, the imposition and the implementation of the attitude of autonomy from the part of the teachers are likely to have dire challenges which entail 1) principal's responsibility to keep close relationship with the governing body of the institute, 2) the share of decisions regarding monetary and budgetary functions with the governing body and 3) principal's obligation to attend and observe national issues engulf the space of the principals not to have time for innovation and creativity [10] (p. 10).

Yet, autonomy is a condition not the implementation for producing of results that leader of the educational institution is likely to think for. The effect of the autonomy is transformational leadership as the power of autonomy creates scope for the institutional heads inclining to transform the institution academically as well as administratively. Now, the burning question is the transformational leader for the educational institution which Colella \& Chirichello [11] has retorted with details to make the idea reliable for the futurism as:

We are experiencing significant global changes. These changes are reflected in all levels of society. A loss of confidence in government, public and private educational institutions, health care delivery systems, religious institutions, aft levels of business and in social agencies is apparent. Traditional values concerning gender issues and the role of the family in society are being challenged. 
Consequently, an individual s ability to assume a proactive posture to change through the process of self-empowerment versus a reactive position is crucial. Encouraging an individual to examine his/her thinking about leadership and the change process is of great importance because this process will enable the individual to create new systems rather than just resisting, coping, managing and struggling with life's changes. (p. 2).

Here lies the urgency of the transformational leaders owing to formulate innovative systems to exponentially raise the prowess of adaptability among the rapid thriving generations with the aptitude of combatting against global changes. But, it is misconception if transformational leaders are justified with the tasks taken to include only the learners of the institutions. The paper [12] opines with an extended dimension of the duties or liabilities of the transformational leaders as these are all inclusive where all the employees of the institutions must be encompassed for the collaborative development necessitating for the adaptation of global trends (p. 2) including socio-economic and cultural-political contexts of the regions.

However, the transformational leadership, the concept of a creative as well as innovative decision-maker who believes in the inclusive development of an institution, not excluding even the lower dignified staffs, needs to be viewed and reviewed through the inverse ideation of aforementioned eulogy. Leonard [13] has denoted several potential problems that a transformational leader may bring; such as-1) tendency to overlook the key problems owing to its nature of smallness and apparently trifling, 2) tending to emphasize on the bigger problems to highlight the contribution and make the work focused for circulation and publication, 3) evaluating only the mentors who work for bigger challenges for the institution leaving behind the other general staffs may raise disgust and animosity among the employees of the institution which can speed up demotivation in them and the leader might consequently fail to make an inclusive progression to attain vision and mission of the institution.

Yet, another concept needs to be addressed with due justification to the fact regarding the term "managerial leadership" as it is likely to gain distinct idea about the distinction of managerial and transformational leadership in order to build firm conviction on the potential necessity of the latter for the educational institutions in the globe of exponentially changing trends. Evaluation to the learners (which is determined through summative, formative and continuous assessment) necessitates for ensuring whether the institution proceeds towards its mission imposed on it [14] (p. 7). The arrangement of evaluation process, the publication of evaluation statistics are strictly relied on the efficient management which the head of the institution needs to manage. The principal or institutional head is provided with an academic calendar and the head chalks out the checklist when to set the time for evaluation. Nevo [14] has come to the point of assumption of two purposes of such type of evaluation which forges the emergence of both managerial as well as transformational leadership out of the institution where the head needs to play both the roles as per the requirements as the re- 
searcher opines that the summative function of the evaluation is to measure if the institution is managing all the institutional components well and next the formative function, that needs immediate action to be taken, which intends to planning for diagnosis the pitfalls (p. 28). Eisner [15] has the identical realization as Nevo. Eisner denotes that a managerial leader of the institution 1) compares the degree of achievement and 2) emphasizes the accountability of the institution through the achievement. Further, he notes that a transformational leader 1) works to diagnose the problems, 2) initiates to revise the curricula if it is required and 3) anticipates educational needs (p. 171).

Akrani [16] denotes ten characteristic traits of a managerial leader which implies his strength as well as weakness. The managerial leader has devotion to work, hypnotizing characteristics, motivational capability which indicate he has self -sufficiency or self-esteem to make a task completed depending on the others. If his motivation fails, the people will react otherwise to flee from the task and it will produce no results. He is a utility leader and if the institution loses the utility, this leader is of no use to the management. He tries to involve every person to attain the goals of the institution but never shares the responsibility to others if the institution weakens in its performance which creates a sense of alienation of the others from the tasks due to their not being collaboratively liable to the failure. A managerial leader, thus, cannot make other a leader in the truest sense.

Thus a managerial leader demonstrates obligation to the task of the institution and inspires the fellow men to perform these in order to achieve the set goals. But this characteristic trait cannot embrace challenges of emerging situations though it may sometimes negate the general rules of code of conduct and legal provisions. This situation claims a transformational leader who enables to break the prejudice of legal guidance as per the demand of the situation.

\section{Methodology}

This paper tends to investigate on the issues of 1) the measurement of effective education, 2) the distinction between managerial and transformational leader and 3) the relation between transformational leadership and effective education from the viewpoint of the principal, the administrative as well as academic head, of Jashore Government Girls' College. Owing to the nature of the study, the targeted population is determined as the principal of the targeted college to measure whether the head prepares himself with gaining the knowledge of recent changes of learners, education policy and educational challenges and find out the roles of the principal to ensure effective education through indicated leadership process. He is targeted to be interviewed for measuring qualitative values of afore-mentioned issues.

\subsection{The Credentials of the Study Area}

The principal has been designed as the reformative leader and the head of the 
colleges (College is dignified with the levels of eleven-twelve, Honours and Masters) of Bangladesh is honoured as the principal. Bangladesh comprises 3239 colleges [17] which can be stratified by two criteria: 1) Student Type and 2) Management System. Table 1 shows the stratification and number of the colleges as follows:

This 3239 colleges of Bangladesh can also be stratified with the view point of administrative management system which implies there are colleges as 1) funded and potentially administered by the policy and rules of the government classified as public colleges and 2) funded and inevitably administered for management by the private initiatives. Table 2 projects the report from BANBEIS [17] to show classification of college of Bangladesh as per Management system:

The study area of this paper is Jashore Government Womens College is a girls' college based on the criterion of typical student enrolment and a public college which is not governed and administered by managing committee, rather this institution is directed as per the policy, rules and regulations of the government of Bangladesh [18]. Table 3 shows the physical conditions of this study area:

\subsection{The Population Demography of the College}

This institution comprises of three major dividends; Higher Secondary (including Science, Arts and Commerce) level and Graduation as well as Post graduation level. According to the statics presented in [19], this institution accords

Table 1. The types and numbers of colleges.

\begin{tabular}{cc}
\hline Student Type colleges & Number of Colleges \\
\hline Boys' colleges & 10 \\
Girls' Colleges & 557 \\
Co-education Colleges & 2672 \\
Total & 3239 \\
\hline
\end{tabular}

Table 2. The classification and number of colleges on management.

\begin{tabular}{cc}
\hline Management System & Number of colleges \\
\hline Public & 607 \\
Private & 2632 \\
Total & 3239 \\
\hline
\end{tabular}

Table 3. The physical dimension of the college.

\begin{tabular}{cc}
\hline Area & 2.89 acres \\
Building & 5 buildings \\
Classroom & 25 classrooms \\
Computer Lab & 1 (33 microcomputers) \\
Multimedia classroom & 3 classrooms \\
Internet connectivity & 1 room (computer lab) \\
\hline
\end{tabular}


5974 students only with the arrangement of 67 class teachers that shows teacher-student ratio as 1:89.16. The students demography can be stated through Figure 1 which projects the information that the science holds 210 students; Arts, 295 and the commerce comprises 147 students and the rest (5322) of the students are taking part the courses for the graduation and post-graduation degrees.

\subsection{Data Collection Procedures and Tools}

Both primary data collected through the interview from the principal is to be used for the purpose of the investigational research and secondary data for the content analysis of the issues and challenges of leadership and effective education is being used to ensure the interlink between transformational leadership, reshaping the idea of traditional managerial leadership, and effective education. Various articles from international journals, blog posts, and the data of the education updates of Bangladesh collected online from various government web pages have been used for secondary data which have been duly referenced at the reference part of the paper.

As the tool of primary data collection from the principal a questionnaire of five questions has been formulated for the response while at the two way conversation between the principal and the author of the paper. The questionnaire is added for the realization of the pivot of interview, such as Table 4 .

\subsection{Data Analysis Technique}

This paper aims at measuring the prevalent situations of the institution, the attitude of the principal towards leadership, the required leadership to ensure effective education on the basis of secondary data and the responses provided by the

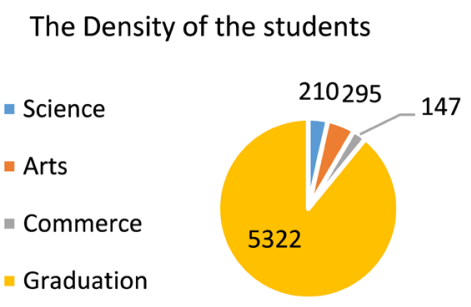

Figure 1. The student density in the college.

Table 4. The questionnaire for the interview of the principal.

\begin{tabular}{cl}
\hline No. & \multicolumn{1}{c}{ Question } \\
\hline 1 & What is your conception about effective education? \\
2 & What are the challenges of ensuring effective education? \\
3 & Do you prefer autonomy to addressing the challenges? \\
4 & Which leadership do you prefer between managerial and transformational leadership? \\
5 & Why?
\end{tabular}


principal. For these purposes, content analysis technique of the responses provided by the principal during interview and the secondary data is relevant to come out of the solution of the problem indicated through the title of the paper. Being a qualitative research, the perception of the principal regarding variables, that is; 1) effective education (dependant variable), 2) managerial and transformational leadership (independent variable) is being measured through content analysis technique. The Data analytic technique is being used for this paper through the use of numerical scale.

\section{Major Findings from Responses}

The findings are documented here based on the responses provided by the principal of the targeted area (Jashore Government Girls' College).

\subsection{The Concept of Effective Education}

The very first question is asked to define the dependent variable "Effective Education" and the principal characterized it on several grounds as:

Question 1:

What is your concept of Effective Education?

1) To raise awareness on the issues of early marriage,

2) To raise interaction out of college with social spheres among the girls,

3) To ensure all the teachers able and interested to conduct multimedia class,

4) To raise computer and ICT (Information and Communication Technology) literacy among the teachers and learners.

\subsection{Challenges to Effective Education}

The second question inquired for delineating, on the part of the principal, the challenges of ensuring quality education from the viewpoint of learners, teachers and institution. The responses were:

Question 2:

What are the challenges of ensuring effective education?

1) To ensure ICT and pedagogical training to all the teachers,

2) To ensure multimedia classroom in every room,

3) To ensure the teachers using digital content in classes,

4) To ensure participation of all the students in various national and social events to increase social liability among the students.

5) To increase funds.

\subsection{The Power of Autonomy}

The principal opined that the government colleges of Bangladesh cannot enjoy financial autonomy. The institutions are allocated budgets by the government concerned authority for yearly basis and some other insignificant funds are derived from various charges taken from students during their admission process. However; all congregated fund is utilized as per the fund utilization sectors de- 
signed by the government and principal is the sole authority in case of any anomaly of expenditure. The Educational Engineering Department is responsible for infrastructural development of a government educational institution and here the principal claims no autonomy. All academic activities are scheduled by the government through an educational calendar year and the college follows that calendar year. But the principal claims autonomy on the students and teachers regarding their code of conduct, their behavior and habit formation.

The Figure 2 that evaluates a leader, basically a transformational leader, on four grounds e.g. 1) ideal, 2) inspirational 3) intellectual and 4) individual consideration designates that an organization head exercises autonomy which the findings from the interview of the principal claims that the principal can have autonomy on the first three elements as per the dealing with teachers, students and guardian affairs except the formulation of curriculum and syllabus to be followed by the teachers as well as the students. But the element fourth, Individualized Consideration, is missing in the case of principal of this type of indicated college explained through the interviews though the principal can influence the way of students' behavior, teachers' disbursement of duty and the way of examination evaluation for the determination of learners' progress. The Figure 3 is indicative on the prevailing scenario of autonomy in the directed type of college identified from the responses of the principal.

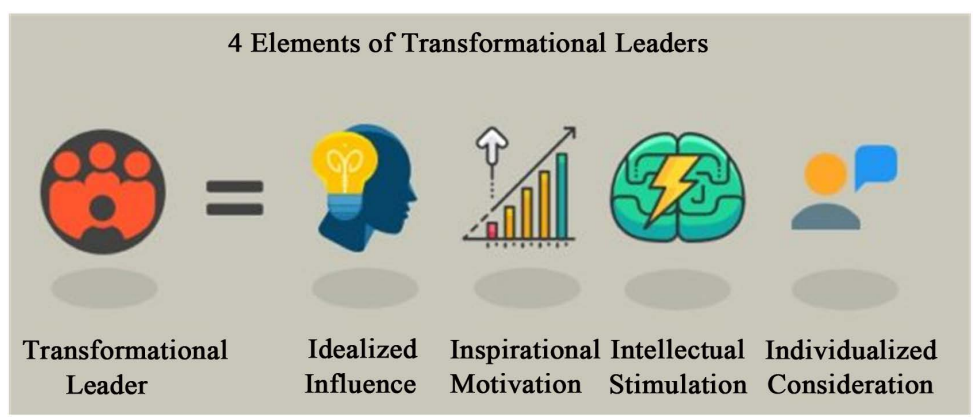

Figure 2. Four elements of transformational leaders [20]. [Source: https://www.projectmanager.com/blog/transformational-leadership].

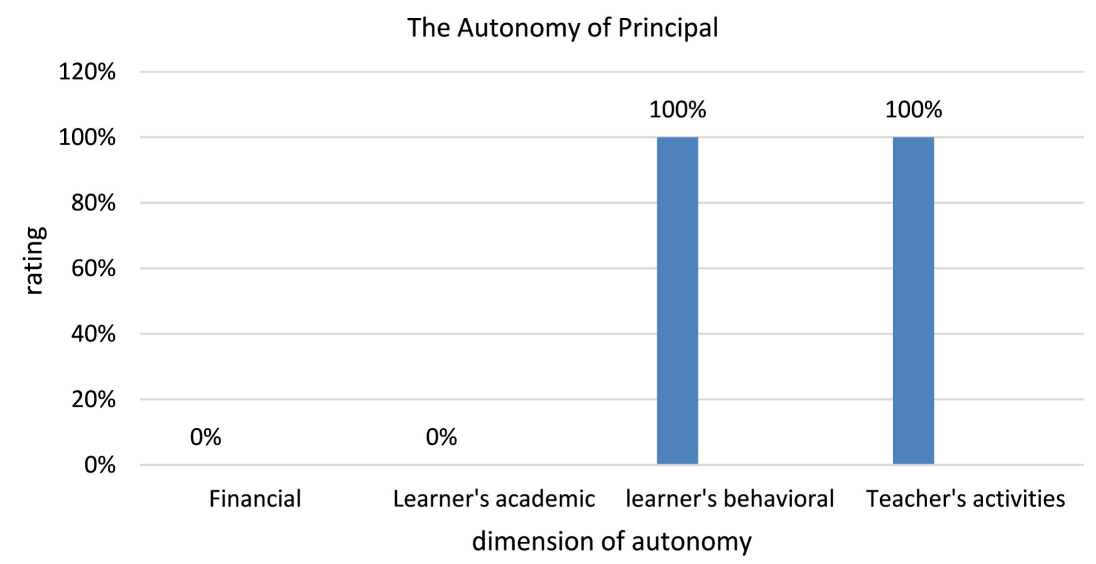

Figure 3. The dimension and rate of principal autonomy. 


\subsection{The Leadership Preference and Innovative Activities}

The questions number 5 and 6 were interlinked which were asked to find data that could be used for demonstrating the prevailing practices in the targeted college assimilating the title and the objectives of the paper.

Questions: 4 \& 5

Which leadership do you prefer between managerial and transformational leadership? Why?

What significant activities do you do beyond legal obligation?

The principal denoted that he preferred transformational leadership more than managerial leadership as to defend his point, he underscored that the institution being a government entity cannot be duly provided with quick response to any urgent issues related to academic as well as administrative activities. Then, the principal needs to take quick decision and make the teachers have faith and credibility on that decision. Here, this idea requires transformational mode of leadership. The principal is used to taking various steps on how to evaluate the students, how to ensure the cent percent presence of the students by calling periodical meetings and sittings with the teachers as well as the guardians of the learners. The principal arranges awarding ceremony for the highest present students on two months basis. He permits debate federation, Blood donation club to operate in the college campus and collect members from the interested students. He also arranges in-house multimedia presentation technique training for the teachers.

\section{The Analysis of the Findings}

The cleaned and stratified data found through survey, interview and investigation are analyzed to make sense of the probable solutions to the problems which the paper identified before [21]. Whether it is data mining or data analytic, the prime purpose of the analysis is to explore and identify the probable solution and this analysis is inevitable to make recommendations and summarize the data which is the prime cause of conducting a research (para. 22). Thus, the findings require analysis to meet the demand of the objectives of the paper.

\subsection{The Indicative Effective Education Parameter}

Ahmed \& Rahaman [22] denotes in their paper that the "Sustainable Development Goals 4" tends to ensure quality education by 2030 which is specified in the "7 Five Year Fiscal Policy" and "Bangladesh Education Policy-2010" characterizing: 1) gender parity, 2) inclusive education and 3) cent percent enrolment in educational institutions in the case of Bangladesh. (pp. 16-17). The finding from the question 1 designates that early marriage prevention fosters effective education which indicates that this type of girls' college experiences students drop out which is due to marriage.

The findings of Rukhsana et al. [23] presents the early marriage rate of Bangladesh has been a decrease in marriage at a young age, particularly before the 
age of 15. Rates of child marriage tend to be lower among younger women than those in older age groups. Figure 2 shows the percentage of currently married women 14 who were married before 15 years, and before 18 years of age. $77 \%$ of women currently aged 45 - 49 were married before they turned 18; the corresponding figure for women who are currently aged $20-24$ is $70 \%$. There is a more noticeable decline in marriages before 15 years of age. $43 \%$ of women currently aged 45 - 59 were married before they reached 15, in comparison to $23 \%$ of women in the age group 15 - 19 years (p. 13) (See Figure 4).

But this rate of early marriage is alarming as it is hampering the cent percent inclusion of girls in secondary and higher secondary education that impedes the girls to reach the arena of tertiary education.

\subsection{The Multimedia Enabling Challenges and Managerial Leadership}

Selvarajah et al. [25] opines that a managerial type of leader seeks for meeting the demands of the organization and they rely mostly on the work and they are influenced by external factors, environmental influences. They are to observe add feminine value that is; sympathy, empathy, emotion, diligence and righteousness to the work and to deal with the organization members. The Figure 5 is taken from reference [25] (p. 94) that designates the roles of a managerial leader.

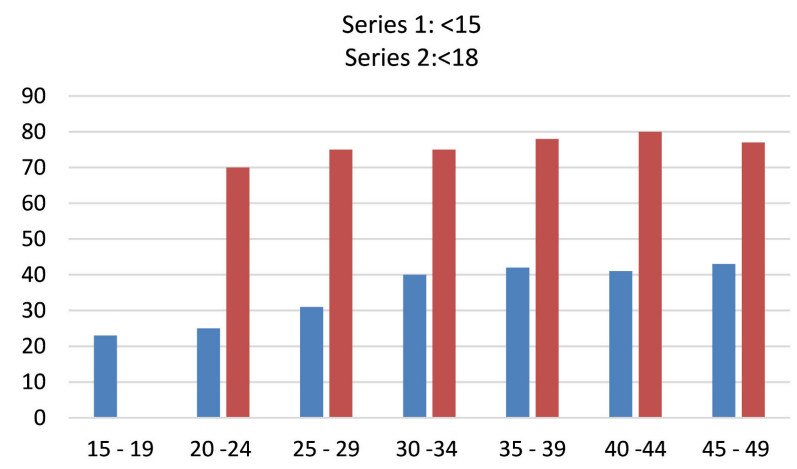

Figure 4. Percentage of currently married women, married by specific ages $(<15$ years, $<18$ years) [24]. [Source:

https://www.researchgate.net/publication/315691208_Child_marriage_in_Bangladesh_Fi $\underline{\text { ndings from_anational_survey_2013] }}$.

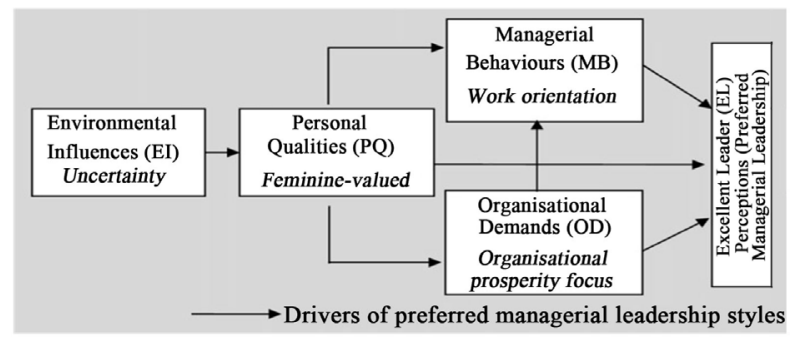

Figure 5. The managerial leadership style. [Source:

https://www.google.com/imgres?imgurl=https\%3A\%2F\%2Fmanagementstudyguide.com]. 
If this is the case for a managerial leader, only to have work orientation and prioritize the organizational demands, the ensuing global trends for the case of educational strategy, for example; the use of innovative tools and techniques for imparting education, the assortment of multimedia tools and making the teachers technologically oriented for maintaining multimedia enabled classes will be far to seek as this type of assortment needs quick decision making from the part of the principal to raise funds, pursuing various projects to be operational in this college to raise the capacity physically without waiting for the government fund to be disbursed [26] (p. 66). This claims a Transformational Leader in operation to address the challenges which are put by the principal in the responses of the question 2. A transformational leader 1) sets goals to address new challenges to reach new height, 2) boosts team members to develop ownership of the work and 3) every member is equally indistinct and every team member's desires are illustrated significantly through the mentoring of the transformational leader [27].

\subsection{Lacking Autonomy to Impede Ownership to the Institution}

The targeted College has been formerly indicated as a government college run by the government directly through the Ministry of Education and the Directorate of Secondary and Higher Education (DSHE) as they are the bodies to make policy of education in Bangladesh [28] and these entities have explicit observation on the government colleges of Bangladesh. Here prevails, both factually and functionally, the presence of managerial leadership to maintain, smoothly conduct, all the procedures through the indicative way formulated and circulated by the Ministry of Education and Directorate of Secondary and Higher Education that approves the role of the principal only being managerial [29]. This designated factor of the study college approves as per the legal obligation of being trifling scope of taking part in the policy making procedures from the part of the principal, the leader and head of the institution, who tends to ensure the implementation of the education policy and programs of the government. The government policy appraises that these typical colleges produce the learners with the administration specified grades or achievement levels to be reached through various nation-wise public examinations, the types of summative assessment and the aims and objectives of the principals in these colleges are set to be vigilant so that the students can achieve the central specified achievements [30]. Sebakwane [31], therefore, has observed that managerial leadership style is the primary and essential type of the principal working in these institutions (though the researcher has termed these institutions as bureaucratic institutions) for the efficacy of the organization.

Salahuddin [32] has speculated on the administrative function of these characteristic colleges of Bangladesh. As the administrative head of the college, the principal is likely to manage how to create adequate infrastructural opportunities for the development of the institution. The principal is to take initiative to develop infrastructure of the college through the government allocation. This 
poses barrier to ensure the standard infrastructural development, the development of lab facilities, inclusion of various teaching tools and aids for every class to guarantee visualization and tactility of learning.

The unavailability of the autonomous power necessary, both academically and administratively, for the principal, may impede girls' access to quality education that the principal referred in the term of explaining "effective education" which can be justified if the reflection of Nandamuri \& Rao [33] is observed:

Each institution has personality of its own and must develop itself to optimize its full potential. Each school is considered, instead of a simple agency for providing educational service, as an independent entity with individually defined specific objectives and managerial practices. The school stands at the centre of the concept and serves as the basis for scientific management practices. In this context the status and perceptions of school heads towards autonomy in terms of administrative autonomy, academic autonomy and financial autonomy are provided hereunder. (p. 5).

This principal of this targeted college is found to have autonomy which makes the principal be only a manager of all the formalities prevalent in this institutions. As the institution lacks ownership, the principal falters to transform the college.

\subsection{Transformational Leadership Preference and Scope for Effective Education}

It is indicated previously that 1) a managerial leader manages the institutions as per the fixed rules, 2) relies on his devotion to work and 3) tries to, impliedly, influence the other team members. But the educational institutions as indicated as study area of this paper are now facing unimagined challenges as: 1) this institution's 5974 students with the assortment of only 67 teachers, 2) the drop out of the students from secondary and higher secondary level for early marriage of the girls, 3) the inability of the teachers to blend pedagogical knowledge with technological knowhow and 4) students' significant shifting to technological oriented learning are the enduring challenges of this institution which needs team work for the all members of this institution to fight against [34].

\section{Conclusion and Recommendation}

\subsection{Recommendation}

The problems of the indicated institution have been dealt with where the managerial leadership seems to be reigned with full freedom though the requirement for the concept of the $21^{\text {st }}$ century quality education is doubted to have been met by this type of leadership practice in this institution. Then, the problem can never be proceeded and extended long for the cause of greater interest of the students. So, the paper recommends that

1) The principal must make all the teachers ownership with the issues and challenges of the institution, 
2) The principal must raise monitoring and vigilant over the activities of the team as a unit,

3) Every member must be listened to by the team leader,

4) The Principal must create scope for the learners to involve in their respective duties and activities such a way they feel indebted equally to the vision and mission of the institution.

Thus, a managerial reclining institutional head can transform himself to a transformational leader if he does not rely on himself for work rather involve every member of this institution to the combat of new challenges and development of the institution as a team responsibility. Here, learners will have to be made believe an essential part of these challenges.

\subsection{Conclusion}

The educational institution of any country needs to remind the truth of the massive technological advancement and the tendency of the learners to be global digitized citizens as per the excerption and the observation of Sankar [5] that an institution, more specifically the institutional head, can never overlook. The learners are technology oriented, the global climate is changing, and the nutritive food intake is one of the major challenges of the $21^{\text {st }}$ century education to meet in order to reach Sustainable Development Goal 4, (Ensuring Quality Education to all by 2030) [35]. The institutional head cannot lag behind to ensure proper training of the $21^{\text {st }}$ century learners to cope up these emerging challenges and this claims transformational leadership of the principal who cannot wait to be provided with instructions from the central authorities; rather, the principal has to decide immediately how to achieve the vision and mission and to what extent and within which time frame these challenges need to be met not by oneself but by combining all the teachers as well as the learners in a team as the essential and inevitable members for the campaign of hope and prosperity.

\section{Conflicts of Interest}

The authors declare no conflicts of interest regarding the publication of this paper.

\section{References}

[1] Ajayi, A. and Ekundayo, H.T. (2011) Factors Determining the Effectiveness of Secondary Schools in Nigeria. The Anthropologist, 13, 33-38. https://doi.org/10.1080/09720073.2011.11891174

[2] Doll Jr., W.E. (1993) The Four R's-An Alternative to the Tyler Rationale. In: Flinders, D.J. and Thornton, S.J. Eds., The Curriculum Studies, 4th Edition, Routledge, Taylor \& Francis Group, New York and London.

[3] Oldroyd, D., Elsner, D. and Poster, C. (1996) Educational Management Today: A Concise Dictionary and Guide. Paul Chapman, London.

[4] Prodhan, M. (2016) The Educational System in Bangladesh and Scope for Improvement. Journal of International Social Issues, 4, 11-23. 
https://www.winona.edu/socialwork/Media/Prodhan\%20The\%20Educational\%20Sy stem\%20in\%20Bangladesh\%20and\%20Scope\%20for\%20Improvement.pdf

[5] Sankar, A. (2010) Technological Gap between Teachers and Students Widen. Gulf News.

https://gulfnews.com/uae/education/technological-gap-between-teachers-and-stude $\underline{\text { nts-widen-1.714232 }}$

[6] Lara, V. (2018) Tailoring Education for the $21^{\text {st }}$ Century: Perspectives from Educators. The Economist Intelligent Unit, The Economist Group. Education. Google. A4.

https://www.blog.google/outreach-initiatives/education/tailoring-education-21st-ce ntury-perspectives-educators/amp/\#referrer=https\%3A\%2F\%2Fwww.google.com\& tff=From $\% 20 \% 251 \% 24 \mathrm{~s}$

[7] Daun, H. and Mundy, K. (2011) Educational Governance and Participation-with Focus on Developing Countries. University of Stockholm, Stockholm.

[8] Pilton, J.W. (2015) International Trends in Principal Autonomy. Lehigh Preserve, Lehigh University, Bethlehem, PA. http://preserve.lehigh.edu/etd/2764

[9] Eyal, O. and Berkovich, I. (2011) National Challenges, Educational Reforms, and Their Influence on School Management: The Israeli Case. Educational Planning, 19, 44-63.

[10] Rodriguez, A. and Hovde, K. (2002) The Challenges of School Autonomy: Supporting Principals. LCSHD Paper Series No. 77, Latin America and the Caribbean Regional Office, United Nations.

[11] Colella, A. and Chirichello, M.P. (1998) Leadership Dynamics. In: Thornton, S.J., Ed., The Curriculum Studies Reader, 2nd Edition, Routledge, New York. https://chrisdavidcampbell.files.wordpress.com/2016/12/doll-1993.pdf

[12] Chirichello, M. (1999) Building Capacity for Change: Transformational Leadership for School Principals. The 12th Annual International Congress for School Effectiveness and Improvement, San Antonio, TX, 3-6 January 1999.

[13] Leonard, K. (2019) Negatives of Transformational Leadership. (Blog Post) https://smallbusiness.chron.com/negatives-transformational-leadership-10533.html

[14] Nevo, D. (1995) School-Based Education: A Dialogue for School Improvement. Pergaman, Oxford.

[15] Eisner, E.W. (1994) The Educational Imagination: On the Design and Evaluation of School Programmes. 3rd Edition, MacMillan, New York.

[16] Akrani, G. (2010) Managerial Leadership-Leader Qualities-Leadership Theories. (Blog Post) https://kalyan-city.blogspot.com/2010/07/managerial-leadership-leader-qualities.html

[17] Bangladesh Bureau of Educational Institutions and Statistics (BANBEIS) (2018) The List of Colleges. http://data.banbeis.gov.bd/images/ban019.pdf

[18] Jashore Government Girls' College (JGMC) (2019) https://www.jgmc.gov.bd

[19] Jashore Government Girls' College (JGMC) (2019). https://www.jgmc.gov.bd/statistics

[20] Hughes, K. (2018) 4 Elements of Transformational Leaders. (PNG) https://www.projectmanager.com/blog/transformational-leadership

[21] Sridhar, J. (2018) What Is Data Analysis and Why Is It Important? (Blog Post) https://www.makeuseof.com

[22] Ahmed, M. and Rahaman, M. (2016) SDG4/Education 2030 and $7^{\text {th }}$ Five-Year Plan of Bangladesh: Aligning National and Global Objectives Strategies and Indicators. 
Bangladesh Education Journal, 9-28.

https://bdplatform4sdgs.net/wp-content/uploads/2016/08/SDG-Education-2030-an d-7-Five-Year-Plan-of-Bangladesh.pdf

[23] Rukhsana, G., et al. (2013) Child Marriage in Bangladesh: Findings from a National Survey 2013.

https://www.researchgate.net/publication/315691208_Child_marriage_in_Banglade sh_Findings_from_a_national_survey_2013

[24] Rukhsana, G., et al. (2013) Percentage of Currently Married Women, Married by Specific Ages ( $<15$ Years, $<18$ Years). (PNG)

https://www.researchgate.net/publication/315691208_Child_marriage_in_Banglade sh_Findings from_anational_survey_2013

[25] Selvarajah, C., Meyer, D., de Waal, A. and Van der Heijden, B. (2018) Dutch Managerial Leadership Strategies: Managing Uncertainty Avoidance, Feminine-Related Social Roles, Organisation Prosperity Focus, and Work Orientation within A Polder Framework. Contemporary Management Research, 14, 87-120.

https://doi.org/10.7903/cmr.18279

[26] Halder, D.P. (2019) The Extent of Problems and Prospects of Enabling Multimedia Classroom in a City Girls' College in Bangladesh. International Journal of Secondary Education, 7, 61-68.

[27] Hughes, K. (2018) How to Manage Better with Transformational Leadership. (Blog Post) https://www.projectmanager.com/blog/transformational-leadership

[28] BANBEIS (Bangladesh Bureau of Educational Information and Statistics) (2007) Education System of Bangladesh. Ministry of Education, Dhaka.

http://www.banbeis.gov.bd/es_bd.htm

[29] BANBEIS (Bangladesh Bureau of Educational Information and Statistics) (2010) Educational Structure of Bangladesh. http://www.banbeis.gov.bd/es_bd.htm

[30] Thornton, H. (2006) Teachers Talking: The Role of Collaboration in Secondary Schools in Bangladesh. Compare: A Journal of Comparative and International Education, 36, 181-196. https://doi.org/10.1080/03057920600741180

[31] Sebakwane, S. (1997) The Contradictions of Scientific Management as a Mode of Controlling Teachers' Work in Black Secondary Schools: South Africa. International Journal of Educational Development, 17, 391-404. https://doi.org/10.1016/S0738-0593(97)00008-4

[32] Salahuddin, A.N.M. (2011) Perceptions of Effective Leadership in Bangladesh Secondary Schools: Moving towards Distributed Leadership? Master's Thesis, University of Canterbury, Christchurch, New Zealand.

[33] Nandamuri, P.P. and Rao, K.V. (2012) Autonomy in School Management-A Policy Perspective. Business Review, 6, 135-148. https://www.researchgate.net/publication/268977849

[34] Sarowardy, M.H. and Halder, D.P. (2019) The Issues and Challenges of Using Multimedia at a District Level, Specialized Girls' College in Bangladesh. Creative Education, 10, 1507-1524. https://doi.org/10.4236/ce.2019.107110

[35] United Nations Organization (UNO) (2016) Sustainable Development Goals. Quality Education. https://www.un.org/sustainabledevelopment/education/ 